\title{
Establishment and Maintenance of Living Structures Made of Willow (Salix) Stems
}

\author{
Yulia A. Kuzovkina
}

\begin{abstract}
Two experimental gardens were installed in Storrs, Connecticut, U.S., to evaluate the potential and limitations of constructing living structures of willow stems as play elements for children. Detailed designs and illustrated descriptions of six structures were developed, which can be accessed on the Internet (www.plantscience.uconn.edu/kuzovkinacv.html). Two clones of Salix miyabeana, previously selected for biomass production, exhibited the required characteristics for growth and stem pliability, low pest susceptibility, and satisfactory performance. The plantings were visually appealing and site maintenance was relatively low. A broader implementation of this innovative practice may appeal to horticulturists, arboriculturists, landscape architects and designers, environmental educators, and school teachers.
\end{abstract}

Key Words. Arboricultural education; children's garden; Salix; willow.

Living installations, or "soft structures" made of woody plants, provide ecologic functions and aesthetic appeal. Living sound barriers are an alternative to conventional noise reduction concrete walls in Europe and Canada (Szczukowski et al. 1998; Labrecque and Teodorescu 2005a). Large-scale green architecture made of living woody poles has been constructed in Germany (Kalberer and Remann 1999, 2003). Another novel usethe construction of living structures as play elements for children-has been introduced in the United Kingdom, Germany, and Denmark (Gro 2004; Warnes 2004). It is based on the union of the traditional craft of basketry with the science of tree growth. Branches are planted as dormant 1.8 to $3 \mathrm{~m}$ (5.9 to 9.9 $\mathrm{ft}$ ) long whips bent into various shapes and configurations. They take root, foliate, and may naturalize to an area.

Willows are amenable for the construction of living structures because they possess fast growth rates and the ability to grow at high planting density, ease of vegetative propagation, rapid establishment from unrooted stem cuttings, rapid resprouting at old nodal areas, and reliable coppicing ability. The last quality ensures a sustainable supply of stems for many years (Keoleian and Volk 2005; Dickmann 2006).

The construction of living structures has been explored by artists, and the knowledge base of the technique is limited to a few articles and books written by craftsmen (Mack and Stender 2004; Warnes 2004). The potential of living structures for public playgrounds has been emphasized in the United States with a small number of artists being engaged in the designs on a local scale (Danks 2002, 2003; Christofer 2006).

Living structures introduce children to the arboricultural practices of planning, planting, growing, pruning, and tending techniques in an entertaining manner while providing them with basic agroforestry experiences. Understanding and working with willow biology is important for the success of the structures, and the basic principles of the technique can be blended into a science curriculum. The introduction of trees as sources of recreation into urban environments raises the social value of trees, promotes experiential learning, and cultivates strong emotional attachment.
To further use this technique, basic arboricultural aspects, including plant selection, establishment, and maintenance, need to be addressed. As part of this investigation, the experimental gardens were installed to provide initial experience, to evaluate the potential and limitations of the technique, and to identify further research questions.

\section{MATERIALS AND METHODS}

Two trial installations were established at the Research Farm of the Department of Plant Science of the University of Connecticut located at Storrs, Connecticut, U.S. (USDA hardiness zones 5/6) in Spring 2006 and 2007. Annual precipitation totaled $1351 \mathrm{~mm}$ (54 in) in 2006 and $1035 \mathrm{~mm}$ (41.4 in) in 2007. Field soil was sandy loam. Both sites were located in full sun. The area for each project measured $21 \mathrm{~m} \times 33 \mathrm{~m}(69.3 \mathrm{ft} \times 108.9 \mathrm{ft})$ or $693 \mathrm{~m}^{2}$ $\left(7,484 \mathrm{ft}^{2}\right)$. Stems of $S$. dasyclados Wimmer (clone 'SV1'), $S$. udensis Trautvetter (clone ' $\mathrm{S} \times 61$ '), and $S$. miyabeana Seemen (clones ' $\mathrm{S} \times 64$ ' and ' $\mathrm{S} \times 67$ ') were received from the State University of New York College of Environmental Science and Forestry in Spring 2006 as dormant $2.4 \mathrm{~m}$ (7.9 ft) long stems with a 2 to $2.6 \mathrm{~cm}$ ( 0.8 to 1.04 in) diameter at the base and 1.2 to $1.5 \mathrm{~cm}(0.48$ to $0.6 \mathrm{in})$ diameter at the tip. For the 2007 installation, stems of the same varieties and same lengths, but with smaller diameters -1.5 to $1.8 \mathrm{~cm}(0.6$ in to 0.72 in) at the base and 0.7 to $0.9 \mathrm{~cm}(0.28$ to $0.36 \mathrm{in})$ at the tips-were used. All stems were cut in March 2006 and 2007, side branches were removed, and the material was stored in a freezer at $-2.2^{\circ} \mathrm{C}$ $\left(28^{\circ} \mathrm{F}\right)$. After removal from the freezer and transportation, the stems were stored in a cooler at $4^{\circ} \mathrm{C}\left(39.2^{\circ} \mathrm{F}\right)$ for 1 to 2 weeks before the planting. During storage, the stems were packaged in plastic bags to prevent evaporation and drying.

During the planning phase in Spring 2006, the blueprint that was used during the 2006 and 2007 installations was developed. Site preparation was accomplished in the fall before the plantings. Existing vegetation on the sites affected the site preparation for each installation resulting in two different approaches. A previously uncultivated site was used for the 2006 installation. After controlling existing weedy vegetation with glyphosate in 
the fall before the installation, the structures were planted into bare, untilled ground. The site required repeated applications of herbicides and hand weeding throughout the next seasons. The area had bare soil paths that were slippery during and after episodes of rain, and the ground was prone to winter heaving. A turf-covered site was used in the 2007 installation and provided effective and attractive ground cover. The establishment of turf eliminated the need for weed control using herbicides or manual labor and created safe and appealing cover for the site. The maintenance requirement included periodic mowing.

It has been previously recommended to cover the planting area for living structures with geotextile fabric or plastic as an alternative method to minimize the weed competition (Warnes 2004). This practice was not implemented here because of the nonbiodegradable nature of the material and limited aesthetic value.

The plantings were installed on 1 to 3 June 2006 and 15 to 17 May 2007. The 2006 plantings grew satisfactorily and were visually appealing. The same design was repeated in the 2007 installation, when the final refinement of the structures was accomplished with the help of Kim Vergil, an artist from Canada. The design was laid out with paint, and the stems were inserted into pilot holes $30 \mathrm{~cm}$ (12 in) deep made with a steel dibble bar. The turf was mowed before painting out the design, and glyphosate was applied along the contours of the structures $30 \mathrm{~cm}(12$ in) wide. The stems were pushed into the ground to the $30 \mathrm{~cm}$ (12 in) depth by applying some pressure without preparing pilot holes. After planting, the stems were thoroughly watered. Plants in both installations received supplemental irrigation only during the first year after the planting and were not subsequently irrigated. Annual topdressing of shredded bark mulch for weed control at the stems' bases was applied to inhibit the weed competition and preserve moisture. At the end of May and in July, the soil at the base of the structures was fertilized using Lesco Professional Starter Fertilizer (18N-24P-12K; Lesco, Cleveland, $\mathrm{OH})$. Table 1 provides a timeline for the major operations that were undertaken for the installations and maintenance requirements of the living structures.

Information recorded throughout the growing seasons included the installation protocol, materials used and a timeline required for each installation, maintenance requirements, and plant performance, including stem survivability as well as insect and disease pressure.

\section{RESULTS AND DISCUSSION}

\section{Design}

Attractive designs were critical to the visual appeal of living structures. Two design goals were addressed: the development of

\begin{tabular}{|c|c|c|}
\hline Year & Season & Activity \\
\hline 0 & Fall & Site preparation: weed control and lawn installation \\
\hline 1 & Spring & Planting, mulching, and watering \\
\hline 1 & Summer & $\begin{array}{l}\text { Watering, fertilization, mowing, weaving or pruning in } \\
\text { August }\end{array}$ \\
\hline 2 & Spring & Fertilization \\
\hline 2 & Summer & $\begin{array}{l}\text { Mowing, pruning once a month in June, July, and } \\
\text { August }\end{array}$ \\
\hline
\end{tabular}

a portfolio of simple modules (individual structures) and the integration of various modules into more complex elements. The individual modules can be used as freestanding elements, may be incorporated into traditional gardens, or integrated into more complex living playgrounds. Although the construction of individual modules required knowledge of basic techniques and a precise design, their integration allowed for much flexibility and site-specific approaches.

A portfolio of modules, ranging from simple arches, wigwams, and arbors to domes, fences, tunnels, and mazes, was developed (Figure 1). Illustrated instructions designed for an inexperienced individual with detailed steps for the construction process can be accessed online (see "Supplementary Materials"). These forms were selected based on major criteria that included simplicity of construction and low maintenance. The incorporation of the modules into a more complex environment was accomplished in the blueprint "Children's Mini-Village" that integrated six modules into a single planting design (Figure 2). The combination of various functional structures-centerpieces (dome, arbor) and linear modules (tunnel, fence and maize)allowed the modules to be linked together thereby increasing the entertainment value of the installation.

\section{Species Selection}

The varieties of willows used for the installations had been previously selected for biomass production in North America. All had exceptional growth characteristics, adaptability to the growing conditions of the northeast, and natural resistance to pests (Tharakan et al. 2005; Labrecque and Teodorescu 2005b). All plants established quickly and performed satisfactorily throughout the period of the study. All varieties foliated in the middle of April and abscised the foliage in the beginning of November. Seasonal changes such as fall leaf coloration were not obvious because foliage remained generally green until abscission. The stems of ' $\mathrm{S} \times 61$ ' were less flexible and not suitable for deep bending. A light infestation of Japanese beetle (Popillia japonica) was observed in 'SV1' in the beginning of July during both years of study. Two clones-' $\mathrm{S} \times 64$ ' and ' $\mathrm{S} \times 67$ 'exhibited the required characteristics for stem pliability and rapid growth, retained clean foliage throughout the season, and exhibited no pest problems.

Species selection is critical, because not all willows are appropriated (Table 2). Basket willow (S. viminalis L.) was not suitable for the northeast region of the United States. Although this species is a "favorite" species for applications in Europe, Canada, and South America (Danks 2002, 2003; Gro 2004; Warnes 2004), it is susceptible to damage by the potato leafhopper (Empoasca fabae) (Smart et al. 2005). White willow (S. alba L.) and its cultivars 'Vitellina' and 'Britzensis' have bright multicolored stems but were very susceptible to willow tar spot (Rhytisma salicinum). The disease, manifested by circular necrotic regions on the leaves by early August, caused early leaf senescence and drop by the end of August, drastically affecting the visual appeal of the plants.

Future species testing should be limited to the subgenus Vetrix, which is characterized by shrub-type growth habit, indeterminate shoot growth producing several flushes of growth, and good pruning and regrowth response (Kuzovkina et al. 2008). This subgenus has extensive fibrous root system with the majority of fine roots found in the upper 40 to $45 \mathrm{~cm}$ (16 to 

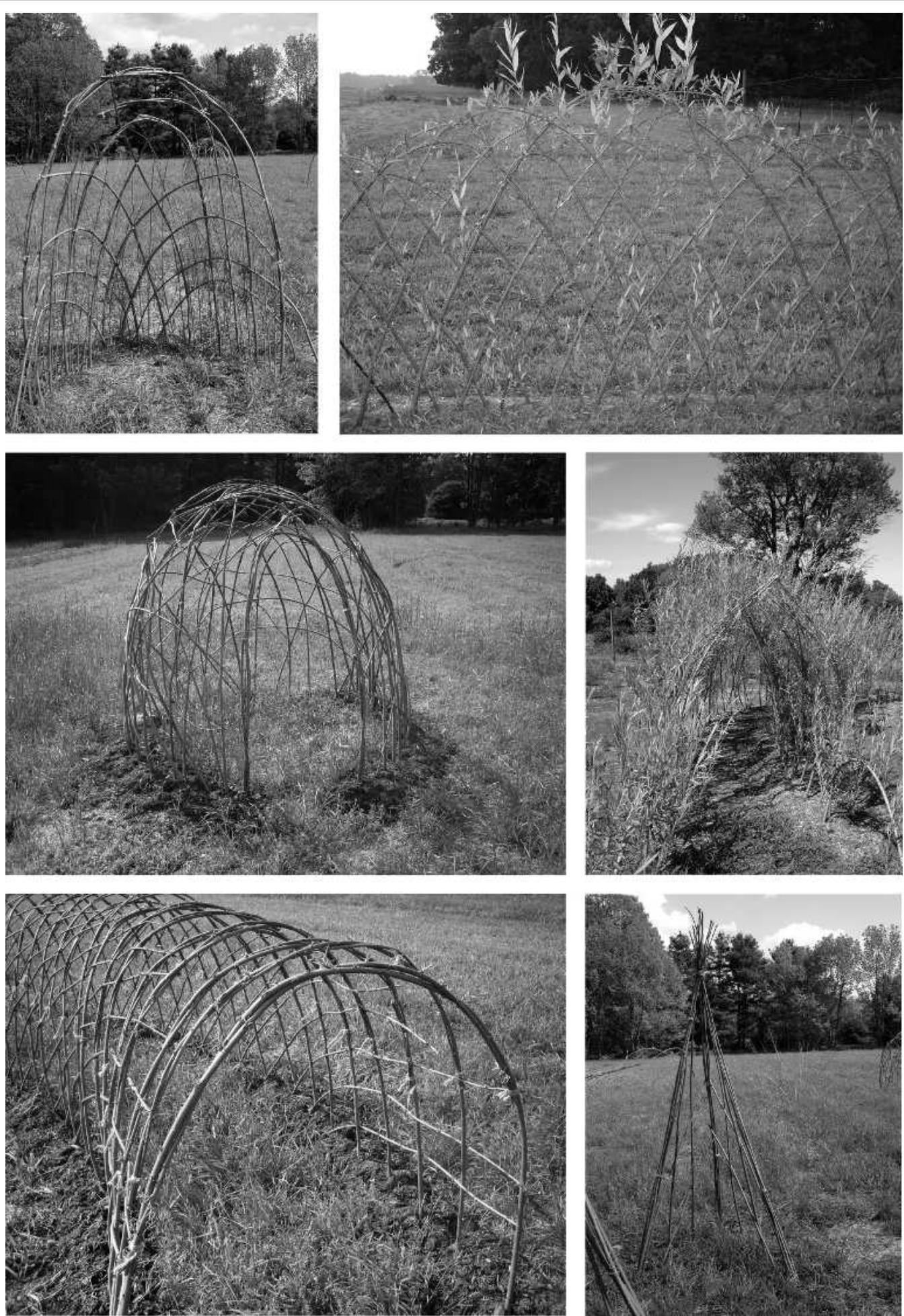

Figure 1. A portfolio of modules of living structures made of willow stems developed during the study.

18 in) of the soil profile, an important feature for the easy removal of plants.

\section{Plant Performance}

Three weeks after the installation, growth was observed on $93 \%$ of the stems. Branches without any vegetative growth were re- placed with fresh dormant stems. At the end of the first growing season, $98 \%$ of stems were alive. No stems died in Year 2. Structures required two growing seasons to mature (Figure 3).

Tip dieback was observed on the upper 10 to $15 \mathrm{~cm}$ (4 to 6 in) of many stems at the end of the second growing season. This problem did not detract from the appearance because they were 


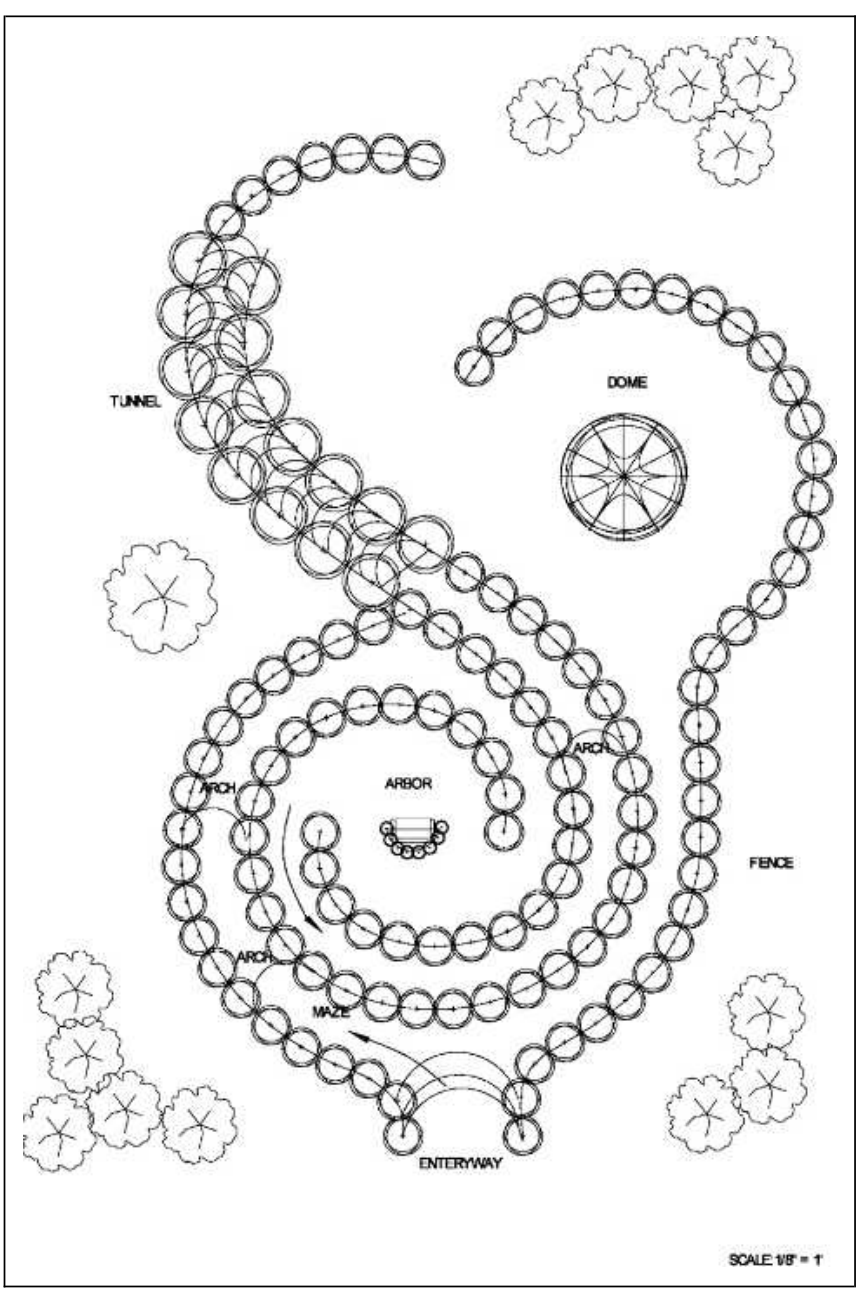

Figure 2. The "Children's Mini-Village" integrated six modules into a more complex environment.

surrounded by healthy lateral branches. Living structures should be considered temporary elements in the landscape.

\section{Lateral Branching}

Stems of smaller diameters were used in 2007. They were easy to bend, had bright color, and produced lateral growth primarily

Table 2. The suitability of Salix taxa for living structures made of willow stems.

\begin{tabular}{clc}
\hline Salix species and clones & Suitability & Limitations \\
\hline $\mathrm{S} \times 64$ (S. miyabeana) & Suitable & No apparent problems \\
$\mathrm{S} \times 67$ (S. miyabeana) & Suitable & No apparent problems \\
$\mathrm{S} \times \mathrm{SV1}$ (S. dasyclados) & Suitable & $\begin{array}{c}\text { Susceptible to Japanese } \\
\text { beetle }(\text { Popillia }\end{array}$ \\
& & japonica) \\
$\mathrm{S} \times 61$ (S. udensis) & Suitable for & Less flexible stems \\
& modules without & \\
& deep bending & \\
Basket willow & Not suitable & Susceptible to the potato \\
(S. viminalis) & & leafhopper (Empoasca \\
& & fabae) \\
White willow (S. alba) & Limited visual & Susceptible to willow \\
and $S$. alba 'Vitellina' & appeal in late & tar spot $($ Rhytisma \\
and 'Britzensis' & summer & salicinum) \\
\hline
\end{tabular}

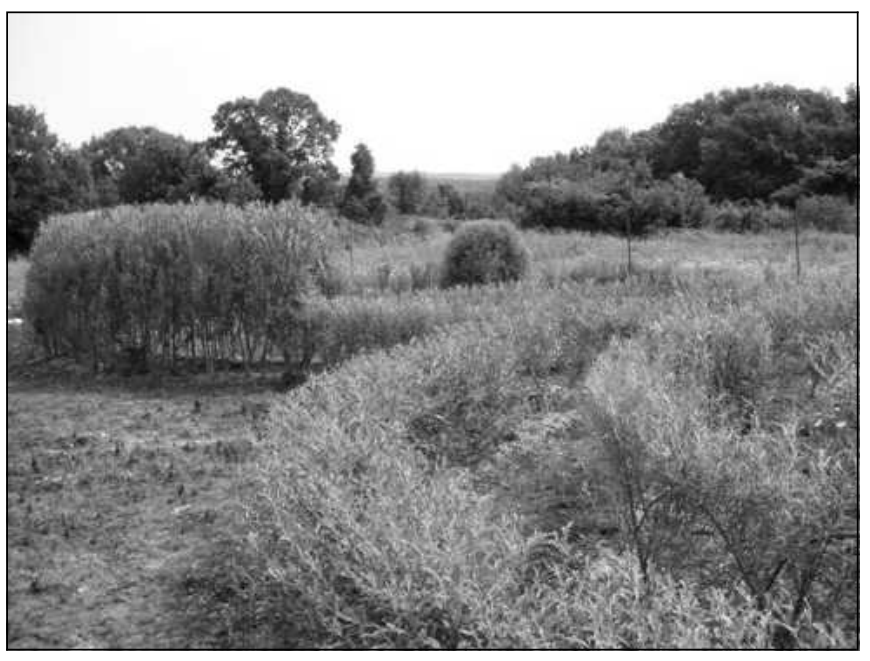

Figure 3. Planted April 2006; photo taken August 2007. Fourteen months were required for the best visual appeal.

on the upper part of the stem (1 m [3.3 ft] from the ground). Stems of thicker diameters were used in 2006. With these, lateral growth was distributed more equally along the stems. Dense lateral growth is highly desirable because it affects the foliage density, the efficiency of shielding, and overall visual appeal.

\section{Weaving and Pruning}

Two cultural practices, weaving and pruning, were used to prevent an unkempt appearance. A weaving technique was performed during the last week of August in 2006 when the growing shoots were long enough ( 0.6 to $1.2 \mathrm{~m} \mathrm{[2}$ to $4 \mathrm{ft}$ ]) to secure the weave. Structures were pruned on a monthly basis at the 2006 installation during the next year and once in August at the 2007 installation by cutting new growth back to a length of 10 to 15 $\mathrm{cm}$ (4 to 6 in) with a power hedge trimmer. The best appearance was achieved by pruning (Figure 4). The resultant new growth maintained foliage density, enhanced overall aesthetics, and emphasized the form. Pruning was found to be less labor-intensive because it required six to eight times less man-hours to shape a structure than weaving (see "Supplementary Materials").

\section{CONCLUSION}

Living structures are relatively simple to execute. The plantings established satisfactorily and required little maintenance.

The lack of an adequate supply of quality planting stock may be a major challenge for the adoption of this practice in the United States because no commercial grower is distributing stems in sufficient quantity and quality. Production practices for growing the stems are those used for willow cultivation as biofuel (Willow Biomass Producer's Handbook 2002; Keoleian and Volk 2005; Labrecque and Teodorescu 2005b). Research on plant selection and dimensions of planting stock, regional demonstration sites, and outreach education materials should be initiated to stimulate further interest and demand for the construction of living structures.

\section{SUPPLEMENTARY MATERIALS}

The following supplementary materials that include the detailed designs and extensive illustrated descriptions of the structures 


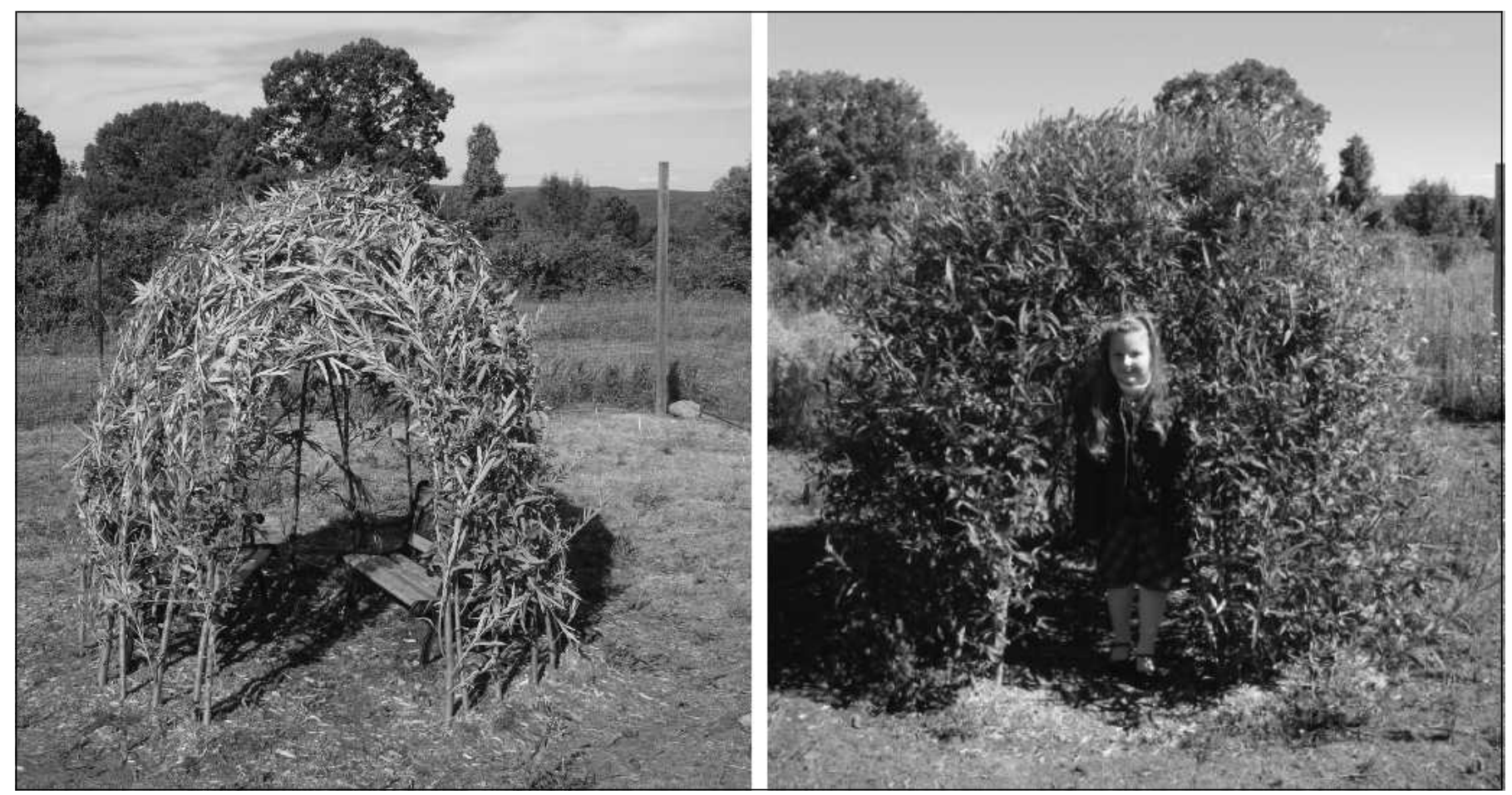

Figure 4. Weaving (left) and pruning (right) resulted in different appearances of the same module.

are available as part of the online article from www.plantscience. uconn.edu/kuzovkinacv.html.

Acknowledgments. I thank Timothy A. Volk (SUNY ESF) for supplying willow stems for this project and an anonymous reviewer for the insightful suggestions and editing of the manuscript. I am also appreciative for the research support from the University of Connecticut.

\section{LITERATURE CITED}

Christofer, T. 2006. One gardener's almanac: Slender reeds, sturdy shoots. House and Garden Magazine March:70-72, 160.

Danks, S.G. 2002. Green mansions. Landscape Architecture June: $38-43,93$.

. 2003. Green mansions: Living willow structure enhance children's play environments. Children, Youth and Environment 13: $37-42$.

Dickmann, D.I. 2006. Silviculture and biology of short-rotation woody crops in temperate regions: Then and now. Biomass and Bioenergy 30:696-705.

Gro, V. 2004. Lebende Weidengeflechte im Garten [in German]. Verlag Th. Schäfer, Hannover, Germany. 95 pp.

Kalberer, M., and M. Remann. 1999. Das Weidenbaubuch [in German]. AT Verlag, Bijz., Munchen, Germany. 127 pp.

2003. Grune Kathedralen [in German]. AT Verlag, Bijz., Munchen, Germany. 127 pp.

Keoleian, G.A., and T.A. Volk. 2005. Renewable energy from willow biomass crops: Life cycle energy, environmental and economic performance. Critical Reviews in Plant Sciences 24:385-406.

Kuzovkina, Y.A., M. Weih, M.A. Romero, J. Charles, S. Hurst, I. McIvor, A. Karp, S. Trybush, M. Labrecque, T.I. Teodorescu, N.B. Singh, L.B. Smart, and T.A. Volk. 2008. Salix: Botany and Global Horticulture. Horticultural Reviews 34:447-489.

Labrecque, M., and T.I. Teodorescu. 2005a. Research note: Preliminary evaluation of a living willow sound barrier along a highway in Quebec, Canada. Journal of Arboriculture 31:95-98. 2005b. Field performance and biomass production of 12 willow and poplars in short-rotation coppice in southern Quebec, Canada. Biomass and Bioenergy 29:1-9.

Mack, D., and T. Stender. 2004. Rustic Garden Furniture. Lark Books, New York, NY. 144 pp.

Smart, L.B., T.A. Volk, J. Lin, R.F. Kopp, I.S. Phillips, K.D. Cameron, E.H. White, and L.P. Abrahamson. 2005. Genetic improvement of shrub willow (Salix spp.) crops for bioenergy and environmental applications in the United States. Unasylva 221:51-55.

Szczukowski, S., J. Tworkowskii, and M. Wiwart. 1998. Application of bush willow (Salix sp.) in environmental shaping and protection. Postepy Nauk Volniczych 4:17-24.

Tharakan, P.J., T.A. Volk, C.A. Nowak, and L.P. Abrahamson. 2005. Morphological traits of 30 willow clones and their relationship to biomass production. Canadian Journal of Forest Research 35: 421-431.

Warnes, J. 2004. Living Willow Sculpture. Search Press, Kent, UK. 48 pp.

Willow Biomass Producer's Handbook. 2002. State University of New York College of Environmental Science and Forestry, Syracuse, NY. $31 \mathrm{pp}$.

\section{Yulia A. Kuzovkina}

University of Connecticut

Department of Plant Science

1376 Storrs Road

Unit 4067

Storrs, CT 06269-4067, U.S.

jkuzovkina@uconn.edu

Résumé. Deux jardins expérimentaux ont été aménagés à Storrs au Connecticut afin d'évaluer le potentiel et les limites des structures construites en végétaux faits avec des tiges de saule comme équipements de 
jeux pour les enfants. Des conceptions détaillées et des illustrations descriptives ont été développés pour six structures qui peuvent être accessibles via l'internet (www.plantscience.uconn.edu/ kuzovkinacv.html). Deux clones de Salix miyabeana, sélectionnés initialement pour la production de biomasse, présentaient les caractéristiques requises de croissance et de flexibilité des tiges, de faible susceptibilité aux parasites et de performance satisfaisante. Les plantations étaient visuellement attirantes et l'entretien des sites relativement faible. Une implantation plus large de cette pratique innovatrice pourrait faire appel aux horticulteurs, aux arboriculteurs, aux architectes paysagistes, aux éducateurs en environnement et aux enseignants scolaires.

Zusammenfassung. In Storrs, Connecticut, wurden zwei experimentelle Gärten errichtet, um die Möglichkeiten und Einschränkungen von lebenden Weidenholzkonstruktionen als Spielelemente für Kinder zu testen. Detaillierte und illustrierte Beschreibungen von sechs Strukturen, die im Internet abzurufen sind, wurden hier entwickelt. Zwei Klone von Salix miyabeana, die ursprünglich für Biomasse gezüchtet wurde, zeigten die erforderlichen Charakteristika für Wachstum und Flexibil- ität, geringe Schädlingsanfälligkeit und eine befriedigende Entwicklung. Die Pflanzungen waren optisch ansprechend und die Instandhaltung war relativ gering. Eine breitere Anwendung dieser innovativen Technik könnte Gärtner, Arboristen, Lehrer und Freizeitpädagogen im weitesten Sinne ansprechen

Resumen. Se instalaron dos experimentos en Storrs, Connecticut, U.S., para evaluar el potencial y las limitaciones de las estructuras vivas de tallos de sauces como elementos de juego para niños. Se desarrollaron diseños detallados y descripciones ilustrativas, que pueden ser consultados en Internet (www.plantscience.uconn.edu/kuzovkinacv.html). Dos clones de Salix miyabeana, previamente seleccionados por su producción de biomasa, exhibieron las características requeridas para crecimiento y flexibilidad del tallo, baja susceptibilidad a plagas, y rendimiento satisfactorio. Las plantaciones fueron visualmente flexibles y el mantenimiento del sitio fue relativamente bajo. Una implementación más amplia de esta innovación práctica puede atraer a los horticulturistas, arboristas, diseñadores y arquitectos del paisaje, educadores ambientales y profesores de escuelas. 